1588 INFLUENCE OF HEMOFILTRATION ON NITROGEN STAGE RENAL DISEASE. Alberto Edefonti, Marisa Giani, Marina Picca, Luciana Ghio, Lucia Romeo, Roberto Rusconi, Fabio Sereni. University of Milan, Department of Pediatrics, Milan, Italy.

Comparative influence of Hemodialysis (HD) and Hemofiltration $(\mathrm{HF})$ on nitrogen balance $(\mathrm{Nb})$ and growth rate (GR) was in vestigated in 8 children, 3 males and 5 females, $11.25 \pm 2.9$ years old . Children were treated first with HD for $25.7+11.9$ months and afterwards with $\mathrm{HF}$ for $19.5+4.1$ months. Nb was evaluated every 2 months by the difference between dietary protein intake (DPD) and protein catabolic rate (PCR), determined by urea kinetics. GR was assessed according with Tanner over a full year period. Results: mean and (SD)

DPl Calorie intake PCR

$\mathrm{g} / \mathrm{kg} /$ day $\mathrm{cal} / \mathrm{kg} /$ day HD 2.04(O.7) 58.1(8.4)

$\mathrm{g} / \mathrm{kg} / \mathrm{day} \mathrm{Nb}$ $2.04(0.6) 6.14(124)$ GR HF $2.2(0.7)$ p NS NS NS $<0.01$ $\mathrm{cm} /$ year $1.9(1.1)$ In conclusion, HF appears to improve growth of children with end stage renal failure previously treated with $H D$, as indicated by both $\mathrm{Nb}$ and GR data. 1591 (RAS) IN CHILDREN. Barbara A. Fivish, Edward J. kuley, Jose R. Salcedo, Barry Potter, Pamela Getson, Glenn H. Bock. George Washington Univ. School of Medicine, Children's Hosp. Nat'1. Med. Ctr., Dept. of Nephrology, Washington, D.C. (Spon. by G.C. Rosenquist).

Unilateral and bilateral RAS are significant and potentially correctable causes of secondary hypertension in children. The technical difficulties and risks of angiography led us to do a retrospective analysis of non-invasive predictors of RAS in 10 consecutive hypertensive children who had renal arteriograms. Five had RAS and all had similar preliminary diagnostic evaluations. Patient ages ranged from 2 to 17 years and there were no differences in sex or age distribution between the RAS and non-RAS groups. An abnormal physical examination (abdominal bruit, cafe-au-lait spots) was highly related to RAS. Further, small sample predictive analysis indicated that a high accuracy of RAS classification may be possible utilizing only the variables of absolute elevations of plasma renin activity and BP $[\mathrm{s} / \mathrm{d} 95 \%$ (BP [s/d $95 \%$ ] is the sum of the age-adjusted difference for systolic and diastolic BP exceeding the 95\%). By contrast, poor correlation with the diagnosis of RAS was found with the following: renal scintillation scanning, depression in blood pressure (BP) using saralasin, and plasma aldosterone. We conclude that physical examination, plasma renin activity and BP $[\mathrm{s} / \mathrm{d} 95 \%]$ are important predictors of RAS and help in the pre-selection of children needing renal angiography. In addition, the value of performing the other diagnostic tests ition, the value of pert
studied is questioned.

\section{$\dagger 1589$}

DOPAMINE RECEPTORS (DR) IN DOG INTRARENAL ARTERIES (IRA). Robin A. Felder, John J. Worthington, and Pedro A. Jose. Dept. of Pediatrics, Georgetown Univ. Medical Center, Washington, D.C.

Dopamine induces renal vasodilatation in the mature canine. Low affinity DR in renal artery and high affinity DR in glomerulus have been reported but no measurements have been made on the arterial segments interposed between these two structures. These experiments characterize, for the first time, DR in dog IRA by radioligand binding using $3 \mathrm{H}$-haloperidol (H). IRA were dissected and homogenized. Specific $\mathrm{H}$ binding was defined as the difference in binding in the presence and absence of $30 \mathrm{uM} \mathrm{cis-f1upenthixol}$ (a potent dopamine antagonist). Kinetic analysis revealed a binding site that saturated in $3 \mathrm{~min}$. and remained at steady state for over $1 / \mathrm{hr}$. The dissociation constant $\left(\mathrm{K}_{\mathrm{d}}\right)$ calculated from kinetic data was $8 \mathrm{nM}$. Competition studies were consistent for DR: LY-141865>YM-09151>cis-flupenthixol=(-)-propranolol>metoclopramide>prazosin $>$ SKF $82526-J$ and stereoselective: (+)-apomorphine $\gg(-)$-apomorphine. Rosenthal plots of saturation data revealed biphasic curves suggestive of multiple classes of binding sites. The high affinity DR site had a $\mathrm{K}_{\mathrm{d}}$ of $2.3 \pm 1.0 \mathrm{nM}$ and a maximum receptor density $\left(B_{\max }\right)$ of $19.5 \pm 5.0 \mathrm{fmol} / \mathrm{mg}$ protein $( \pm S E M, n=5)$. For the low affinity site the $\mathrm{K}_{\mathrm{d}}$ was $31.8 \pm 1.7 \mathrm{nM}$ and the $B_{\max }$ was $92 \pm 20 \mathrm{fmol} / \mathrm{mg}$ protein $(n=5)$. These results suggest that the adult canine IRA contain specific DR. The specific DR-2 antagonist YM09151 and the DR-2 agonist LY-141865 were more potent than the relatively DR-1 selective antagonist cis-flupenthixol and DR-1 agonist SKF 82526-J respectively suggesting that the predominant $\mathrm{DR}$ in the canine IRA is of the DR-2 subtype.
THE RENAL ALPHA $(\alpha)$ ADRENOCEPTOR MEDIATING SODIUM

TRANSPORT. Robert D. Fildes, Gilbert M. Eisner, and Pedro A. Jose. Georgetown Univ. Med. Ctr., Wash. D.C. The putative roles of $\alpha-1$ and $\alpha-2$ adrenoceptors in renal tubuar sodium transport led us to compare the effects of intrarenal infusions in adult dogs of phentolamine ( $P h)$, an $\alpha-1, \alpha-2$ adrenergic antagonist $(n=6)$, prazosin $(P r)$ an $\alpha-1$ antagonist $(n=6)$, and yohimbine (Y), an $\alpha-2$ antagonist $(n=6)$ on renal hemodynamics and sodium excretion. Mean arterial blood pressure, renal blood flow and glomerular filtration rate did not change during the infuand glomerular filtration rate did not change during the infu-
sions. Sodium excretions (UNaV-uEq/min/g kidney) were $\mathrm{M} \pm \mathrm{SEM}$ :

$\begin{array}{cccc}M & \mathrm{Ph} & \mathrm{Pr} & \mathrm{Y} \\ \text { Contr } 1 & 0.16 \pm .04 & 0.34 \pm .10 & 0.22 \pm .05 \\ 2 \times 10^{-8} & 0.35 \pm .09 * & 0.66 \pm .12^{*} & \\ 1 \times 10^{-7} & 0.42 \pm .09 * & 1.01 \pm .21^{*} & \\ 3 \times 10^{-7} & 0.60 \pm .16^{*} & 1.17 \pm .15^{*} & 0.39 \pm .07 * \\ 1 \times 10^{-5} & & & 0.46 \pm .08 * \\ 2 \times 10^{-5} & & & 0.54 \pm .12 *\end{array}$

$M=$ Intrarenal molar concentration:* $<0.05$ paired test vs control.

The changes in fractional sodium excretion paralleled UNaV. Lineweaver-Burk plots indicated that maximum percent response $\left(\mathrm{E}_{\max }\right.$ ) were $242 \% \mathrm{Ph}, 279 \% \mathrm{Pr}$ and $128 \% \mathrm{Y}$ respectively. The $\mathrm{M}$ concentrations producing an effect equal to $\mathrm{E}_{\max } / 2$ were $1.4 \times 10^{-8}$ for $\mathrm{Ph}, 1.8 \times 10^{-8}$ for $\mathrm{Pr}$, and $1.4 \times 10^{-7}$ for $\mathrm{Y}$. The $\mathrm{y}$-intercept $\left(1 / \mathrm{E}_{\max }\right)$ for $P r$ was different from $Y$ indicating actions on different adrenoceptors. This is supported by the fact that the addition of Pr $\left(2 \times 10^{-7} \mathrm{M}\right)$ to $\mathrm{Y}\left(5 \times 10^{-6 \mathrm{M}}\right)$ significantly increased uNaV from 0.87 +0.11 to $1.35+0.23 \mathrm{mEq} / \mathrm{min} / \mathrm{g}$ kidney $(\mathrm{n}=3)$. Thus both $i x-1$ and $i t-2$

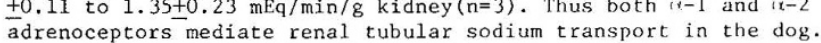

CYSTINE UPTAKE BY CULTURED HUMAN RENAL CORTEX CELLS.

1592 J.W. FOREMAN, B. STATES AND S. SEGAL. U. of PA School of Med., Chíldren's Hosp., Dept. of Peds., Phila., PA In vitro studies of human renal transport have been limited in part because of the difficulty in obtaining adequate tissue. Cell culturing techniques afford the opportunity to perform such studies with limited amounts of tissue. Starting with small samples of normal human cortex obtained at nephrectomy for cancer, we wexe able to culture renal cortex epithelial cells that were free of fibroblast contamination by using a hormonally defined, serumfree medium. These cells proliferated and formed a monolayer, adhering to the surface of the culture flask. The cells could be passed for up to $5-6$ times. The cell membrane facing the media had microvilli. There were connections between the cells resembling the tight junctions observed in vivo between renal tubule cells. When they were nearly confluent, "dome" formation, the lifting of the monolayer off the supporting structure, occurred suggesting active sodium and water movement. Dome formation became more evident with the addition of fetal calf serum to the medium. The cultured cells had alkaline phosphatase activity on the plasma membrane suggesting a proximal tubule origin. Because of this proximal tubule characteristic, we examined the ability of these cultured cells to transport the amino acid cystine. The monolayer progressively transported ${ }^{35} \mathrm{~S}$-cystine for up to $60 \mathrm{~min}$. of incubation. Lysine inhibited cystine uptake by these cells. This is the first in vitro evidence for the interaction between cystine transport and lysine which has been observed in vivo in the human kidney. Cultured renal cortex cells offer a new approach to the study of renal transport in humans.
153 PERITONEAL MASS TRANSFER (MT) OF MINERALS AND 3ONE1593 MODULATING HORMONES IN CHILDREN ON CONTINUOUS AMBULAGaston Zilleruelo, Carolyn Abitbol, Kuo H. Hwang, Jacques J. Bourgoignie, Jose Strauss. Dept. of Pediatrics and Medicine, University of Miami, Miami, Florida.

Abnormal mineral metabolism (MM) has profound consequences in uremic children. To evaluate the impact of CAPD on MM we performed 52 serial MT studies ( $\bar{x} 9$ studies/patient) in 7 children 1 week to $16 \mathrm{yr}$. old maintained on CAPD from 1 to 18 months.

Net daily peritoneal losses averaged $18 \pm 25 \mathrm{mg}$ (range +28 to -58 ) for $\mathrm{Ca}, 175 \pm 112 \mathrm{mg}(-34$ to -382$)$ for $\mathrm{P}, 18 \pm 6 \mathrm{mg}(-9$ to -30$)$ for $\mathrm{Mg}$, $6 \pm 4.5 \mathrm{Hg}(-1$ to -15$)$ for $25 \mathrm{OH}$ vitamin $\mathrm{D}$, and $28 \pm 20 \mathrm{ng}(-1.5$ to -58 ) for $1,25(\mathrm{OH})_{2}$ D. Losses of $25 \mathrm{OH}$ and $1,25(\mathrm{OH})_{2}$ D represented $41 \%$ and $105 \%$, respectively, of the circulating pool. Progressive + of plasma $25 \mathrm{OH} \mathrm{D}(37$ to $22 \mathrm{ng} / \mathrm{ml})$ and $1,25(\mathrm{OH}){ }_{2} \mathrm{D}(74$ to $17 \mathrm{pg} / \mathrm{ml})$ was noted in 3 pats.; iPTH was readily detectable in peritoneal exchanges $(352 \pm 265 \mu 1 \mathrm{Eq} / \mathrm{ml})$ and $\bar{x}$ serum iPTH + by $30 \%$ (394 to 280 $\mu 1 \varepsilon_{q} / \mathrm{m} 1$, normal 10 to 90 ) during $\bar{x} 7 \mathrm{mo}$. observation. Hypermagnesemia $(3.1 \mathrm{mg} / \mathrm{dl})$ normalized $(2.2 \mathrm{mg} / \mathrm{dl})$ using low-magnesium dialysate $\left(\mathrm{PD}_{2}\right.$ Dianeal $\left.{ }^{\mathrm{R}}\right)$. Serum Ca correlated negatively with $\mathrm{Ca}$ MT $(r=-0.61, p<0.01)$ and positively with \% decline in serum iPTH $(r=0.81, p=0.05)$. Serial bone radiographs were mostly unchanged. (hus, CAPI) in children: 1) adequately removes $\mathrm{P}$ and $\mathrm{Mg} ; 2$ ) lcads to minimal Ca losses; 3) substantially removes PTH but also vitamin metabolites, and 4) improves hyperparathyroidism and hypermagnesemia. 